\title{
Carbon Allocation, Belowground Transfers, and Lipid Turnover in a Plant-Microbial Association
}

\author{
Francisco J. Calderón* \\ USDA-ARS \\ Central Great Plains Research Station \\ 40335 County Rd. GG \\ Akron, CO 80720
}

David J. Schultz

Dep. of Biology

Univ. of Louisville

Louisville, KY 40292

Eldor A. Paul

Natural Resource Ecology Lab. Colorado State Univ.

Fort Collins, CO 80523
Radioactive tracers were used to study the $C$ allocation to coarse and fine roots, aboveground plant tissues, mycorrhizal lipids, belowground respiration, and soil in a mycorrhizal association. Sorghum bicolor (L.) Moench was grown in soil with a nonmycorrhizal microbial inoculum with and without Glomus clarum, a mycorrhizal inoculant. Fifty-one-day-old mycorrhizal (M) and nonmycorrhizal (NM) plants were subjected to a 3-h exposure to ${ }^{14} \mathrm{CO}_{2}$ and sequentially harvested after 52, 54, 57, 64, and $76 \mathrm{~d}$. Mycorrhizal plants assimilated $21 \%$ more ${ }^{14} \mathrm{C}$ than NM plants, even though they were slightly smaller in size. They also had a higher percentage and absolute allocation of ${ }^{14} \mathrm{C}$ to root tissue, belowground respiration, and soil. Mycorrhizal roots had a higher content of total lipids and total fatty acids. The fungal fatty acid 16:1 $\omega 5$, usually associated with arbuscular mycorrhizal fungi, comprised up to $29.5 \%$ of the total fatty acid content of $M$ roots, while NM roots had only trace levels of this molecule. Thin-layer chromatography was used to separate the fatty acids extracted from the roots. The ${ }^{14} \mathrm{C}$ of the various components was determined by radiography. The ${ }^{14} \mathrm{C}$ mean residence time (MRT) of the mycorrhizal fatty acid $16: 1 \omega 5$ was calculated at $7.1 \mathrm{~d}$. The monoenoic, saturated, and total fatty acids had MRTs ranging from 11.1 to $14.3 \mathrm{~d}$. The lipids of $\mathrm{NM}$ roots incorporated less ${ }^{14} \mathrm{C}$ label. This underscores the difference in the lipid $C$ cycle between the $M$ and NM roots. Translocation of the ${ }^{14} \mathrm{C}$ to soil was $6.3 \%$ of the photosynthesized $C$ in the $M$ plants relative to only $2.4 \%$ in the NM plants, giving an indication of its movement into the mycorrhizal hyphae as well as to the soil.

Abbreviations: AMF, arbuscular mycorrhizal fungi; $M$, mycorrhizal; MRT, mean residence time; NM, nonmycorrhizal; PVC, polyvinyl chloride; TLC, thin-layer chromatography.

$\mathrm{T}$ The mycorrhizal association is an important factor in the retention or loss of $\mathrm{C}$ in terrestrial ecosystems as well as in plant nutrition. The balance between above- and belowground plant productivity, as well as mycorrhizal fungal growth and rhizosphere and soil respiration depends on the type of symbiotic system, soil moisture, temperature, nutrient status, and atmospheric $\mathrm{CO}_{2}$ levels (Rillig and Allen, 1999). It is difficult in calculating atmospheric-soil $\mathrm{CO}_{2}$ transfers to know whether mycorrhizal respiration is to be considered as autotrophic or heterotrophic and how much the microbial associations affect belowground allocations. Hobbie (2006) estimated that ectomycorrhizal fungal net productivity could reach $21 \%$ of the total net primary production. This is above the 1 to $6 \%$ value usually applied to arbuscular mycorrhizal fungi (AMF) (Warembourg and Paul, 1973; Snellgrove et al., 1982). Plants infected with mycorrhizal fungi have higher $\mathrm{C}$ respiration due to increased flow of $\mathrm{C}$ to the root system (Jakobsen

The USDA is an equal opportunity provider and employer.

Soil Sci. Soc. Am. J. 76:1614-1623

doi:10.2136/sssaj2011.0440

Received 20 Dec. 2011.

*Corresponding author (francisco.calderon@ars.usda.gov).

(C) Soil Science Society of America, 5585 Guilford Rd., Madison WI 53711 USA

All rights reserved. No part of this periodical may be reproduced or transmitted in any form or by

any means, electronic or mechanical, including photocopying, recording, or any information storage and retrieval system, without permission in writing from the publisher. Permission for printing and for reprinting the material contained herein has been obtained by the publisher. 
and Rosendahl, 1990) but also fix more C as photosynthate (Finlay and Soderstrom, 1992; Staddon et al., 1999).

Molecular techniques are providing quantitative analysis of mycorrhizal communities and the genes involved in transport mechanisms (Balestrini et al., 2011). Kramer and Gleixner (2006) utilized both ${ }^{13} \mathrm{C}$ and ${ }^{14} \mathrm{C}$ to differentiate the use of plant- and soil-derived $\mathrm{C}$ by soil microbes, but the use of ${ }^{14} \mathrm{C}$ provides greater sensitivity in the measurement of the different pools involved (Wiesenberg et al., 2010). Fatty acids are especially useful in such studies because they can be relatively easily isolated from either soil or plant parts, and individual compounds act as biomarkers for the different components of the plant-soil biota (Leake et al., 2006; Denef et al., 2009). Olsson and Johnson (2005) used ${ }^{13} \mathrm{C}$ tracers to study $\mathrm{C}$ dynamics and incorporation into signature fatty acids in a Glomus-Plantago symbiosis. It is challenging to directly measure the $\mathrm{C}$ allocated to intraradical mycorrhizal cells. The close association of the root and the fungus limits the feasibility of a physical separation (Tinker et al., 1994). Most studies have involved laboratory systems with and without the mycorrhizal fungi (Pang and Paul, 1980; Paul and Kucey, 1981).

Lipids play an important role in the $\mathrm{C}$ economy of the arbuscular mycorrhizal association and are used as the main $\mathrm{C}$ storage molecules (Cox et al., 1975; Bago et al., 1998). The higher lipid content of mycorrhizae indicates that infected roots have higher construction costs than nonmycorrhizal roots. Many species of AMF contain high amounts of the fatty acid 16:1 $\omega_{5}$, which is absent in nonmycorrhizal roots (Beilby, 1980; Nagy et al., 1980; Nordby et al., 1981; Grandmougin-Ferjani et al., 1997; Calderón et al., 2009). Recent studies have shown that there is a rapid incorporation of photoassimilated C into soil phospholipids, with the greatest accumulation of radiolabel occurring as 16:1w5 (De Deyn et al., 2011). Data are lacking, however, on C incorporation and turnover into lipids of mycorrhizal and nonmycorrhizal $\mathrm{C}_{4}$ plants.

The AMF lipids offer the opportunity to determine the turnover of a large component of the AMF by the pulse incorporation of ${ }^{14} \mathrm{C}$, followed by sequential measurements of the radioactive signal in AMF-specific and plant lipids, fine and coarse roots, soil, and respired $\mathrm{CO}_{2}$.

In this experiment, we aimed to explore two hypotheses. The scarcity of data about the estimated $\mathrm{C}$ contribution to soil in mycorrhizal $\mathrm{C}_{4}$ plants prompted us to hypothesize that $6 \%$ of photosynthate $\mathrm{C}$ will be transferred to the soil via growing $\mathrm{AMF}$ hypha and hyphal-derived C compounds. This is in line with what has been found for other plant-AMF symbioses growing in soil. Few studies have quantified the dynamics of $16: 1$ w5 C in roots to validate the assumption that it is a fungal pool in the mycorrhizal association. We hypothesized that 16:1 15 is a Glomus clarum specific fatty acid, and its $\mathrm{C}$ turnover rate corresponds to AMF energy production and $\mathrm{CO}_{2}$ release from mycorrhizal roots. Besides these two hypotheses, we had the following specific objectives: (i) to measure the patterns of $\mathrm{C}$ incorporation and retention in the plant tissues, root lipids, soil, and soil respiration by mycorrhizal and non mycorrhizal sorghum, (ii) measure the turnover of $\mathrm{C}$ in the AMF-specific and nonspecific lipids of the mycorrhizal roots, and (iii) calculate the turnover rate of the belowground constituents.

\section{MATERIALS AND METHODS}

Each plant was grown in a polyvinyl chloride (PVC) cylinder (9.6- $\mathrm{cm}$ diameter, $20-\mathrm{cm}$ height) containing $2 \mathrm{~kg}$ of sieved (5-mm) sandy loam ( $\mathrm{pH} 6.2$, cation exchange capacity $4.5 \mathrm{cmol} \mathrm{kg}^{-1}, 1.2 \%$ organic matter, $12.5 \mathrm{mg} \mathrm{kg}^{-1}$ total $\mathrm{P}$, $88.0 \mathrm{mg} \mathrm{kg}^{-1} \mathrm{~K}, 647.5 \mathrm{mg} \mathrm{kg}^{-1} \mathrm{Ca}$, and $121.5 \mathrm{mg} \mathrm{kg}^{-1} \mathrm{Mg}$ ). The soil was collected from the Ap horizon of a Kalamazoo loam (a fine-loamy, mixed, mesic Typic Hapludalf) in Michigan. The soil was sterilized by irradiation with ${ }^{60} \mathrm{Co}\left(13 \mathrm{~h}, 3826 \mathrm{~Gy} \mathrm{~h}^{-1}\right)$. Seeds of S. bicolor were surface sterilized (70\% ethanol for $30 \mathrm{~s}$, then $20 \%$ bleach for $20 \mathrm{~min}$ ). The seeds were germinated in a petri dish for $2 \mathrm{~d}$ over a sterile filter paper. Two germinated seeds were planted per pot and thinned to one after the first week of the experiment.

The pots in the mycorrhizal treatment $(\mathrm{M})$ were inoculated with Glomus clarum Nicolson \& Schenck (INVAM BR147B-4) by adding a 50-g mixture of infected roots and soil-borne spores. The nonmycorrhizal treatment (NM) received no roots, but a chlamydospore-free filtrate of the mycorrhizal inoculum was added to supply nonmycorrhizal soil microbes to the NM treatment.

A total of 40 plants (20 M and $20 \mathrm{NM}$ ) were placed inside a 5.4- $\mathrm{m}^{3}$ Plexiglas chamber with a sealed wood frame and base and placed inside a greenhouse. The chamber was open to allow air exchange and equilibration to greenhouse conditions until the time of the pulse labeling. The plants were grown with natural light supplemented with high-pressure Na lamps placed outside the chamber. The photosynthetically active radiation ranged from 250 to $1200 \mu \mathrm{mol} \mathrm{L} \mathrm{L}^{-1} \mathrm{~m}^{-2} \mathrm{~s}^{-1}$ during the 16 -h photoperiod. The temperature ranged from 23 to $29^{\circ} \mathrm{C}$. Each pot received $300 \mathrm{~mL}$ of a P-free nutrient solution (1.5 mmol L $\mathrm{maCl}_{2}, 0.5 \mathrm{mmol} \mathrm{L}^{-1} \mathrm{~K}_{2} \mathrm{SO}_{4}, 2.5 \mathrm{mmol} \mathrm{L}-1$ $\mathrm{NH}_{4} \mathrm{NO}_{3}, 0.25 \mathrm{mmol} \mathrm{L}{ }^{-1} \mathrm{MgSO}_{4}, 25 \mu \mathrm{mol} \mathrm{L}{ }^{-1} \mathrm{H}_{3} \mathrm{BO}_{3}$, $20 \mu \mathrm{molL}^{-1} \mathrm{FeDDHA}, 20 \mu \mathrm{molL}^{-1} \mathrm{ZnSO}_{4}, 0.5 \mu \mathrm{molL}^{-1} \mathrm{CaSO}_{4}$, $0.4 \mu \mathrm{mol} \mathrm{L}^{-1} \mathrm{H}_{2} \mathrm{MoO}_{4}$, and $0.6 \mu \mathrm{mol} \mathrm{L}-1 \mathrm{CoCl}_{2}, \mathrm{pH}$ to 6.8 with $\mathrm{KOH}$ ) and was watered to field capacity with distilled water every $2 \mathrm{~d}$. Plants were subjected to a single exposure of ${ }^{14} \mathrm{CO}_{2} 51 \mathrm{~d}$ after planting when they were approaching the reproductive phase. A total of $92 \mu \mathrm{mol} \mathrm{L}^{-1}$ of labeled $\mathrm{C}$ in the form of $\mathrm{Na}_{2}{ }^{14} \mathrm{CO}_{3}$, with a specific activity of $0.1542 \mathrm{GBq} \mathrm{kg}{ }^{-1} \mathrm{C}$ was used. The labeled $\mathrm{Na}_{2}{ }^{14} \mathrm{CO}_{3}$ was mixed with unlabeled $\mathrm{Na}_{2} \mathrm{CO}_{3}$ to form a $0.77 \mathrm{~mol} \mathrm{~L}^{-1}$ solution. The concentration of the $\mathrm{CO}_{2}$ in the chamber was maintained at ambient levels by monitoring the internal $\mathrm{CO}_{2}$ concentration with an infrared gas analyzer and generating labeled $\mathrm{CO}_{2}$ as needed. The ${ }^{14} \mathrm{CO}_{2}$ was produced by reacting the $\mathrm{Na}_{2} \mathrm{CO}_{3}$ solution with an excess $85 \%$ lactic acid. A total of $170.2 \mathrm{MBq}$ were added to the chamber during a 3-h labeling period. The chamber was purged with fresh air at the end of the pulse labeling at a rate of $18 \mathrm{~m}^{3} \mathrm{~h}^{-1}$. 
Five harvests were performed 1, 3, 6, 12, and $24 \mathrm{~d}$ after the ${ }^{14} \mathrm{CO}_{2}$ exposure. At each harvest, the shoots were separated from the roots by clipping and the soil and shoots were placed at $-20^{\circ}$. The shoots were dried $\left(65^{\circ} \mathrm{C}, 24 \mathrm{~h}\right)$, ground, and then stored at $5^{\circ} \mathrm{C}$ until the nutrient and biomass analyses. The roots were separated from the soil first by gently separating them from the bulk of the surrounding soil, then by washing any remaining soil clinging to the roots with water while retaining the roots in a sieve. After washing, the material was freeze-dried and the biomass of the fine ( $<1-\mathrm{mm}$-diameter) and coarse $(>1-\mathrm{mm}$-diameter) roots was recorded. The root material was freeze-dried and stored at $4^{\circ} \mathrm{C}$ until the lipid and radioactivity analyses.

To measure shoot $\mathrm{P}$ concentration, samples $(0.5 \mathrm{~g})$ were ashed $\left(500^{\circ} \mathrm{C}, 5 \mathrm{~h}\right)$ and digested for $1 \mathrm{~h}$ in $25 \mathrm{~mL}$ of $3 \mathrm{~mol} \mathrm{~L}^{-1}$ $\mathrm{HNO}_{3}$ in $1 \mathrm{~g} \mathrm{~kg}^{-1} \mathrm{LiCl}$. The digests were filtered and mixed with a $0.3 \mathrm{~mol} \mathrm{~L}^{-1} \mathrm{NaOH}$ solution $(1: 9 \mathrm{v} / \mathrm{v})$. These were then analyzed colorimetrically with a Lachat Flow Injection Analyzer (Zeller Analytical). The total shoot P ranged from 10.3 to $12.2 \mathrm{mg} \mathrm{plant}^{-1}$ and was statistically indistinguishable between the $\mathrm{M}$ and NM plants.

Ground shoot and root samples were analyzed for specific activity and $\mathrm{C}$ content. The samples were combusted with a biological sample converter (Europa Scientific Roboprep-CN) in series with a mass spectrometer (Europa Scientific 20-20 Stable Isotope Analyzer). The $\mathrm{C}$ content of the samples was determined by comparison with sucrose standards. The $\mathrm{CO}_{2}$ evolved by combusting the samples was trapped in Carbon 14 Cocktail (R.J. Harvey Instrument Co.) and the radioactivity was measured by liquid scintillation. The effectiveness of the traps was estimated by analyzing ${ }^{14} \mathrm{C}$ leucine of known mass and specific activity. Samples of freeze-dried fine roots $(0.02 \mathrm{~g})$ were analyzed by gas chromatography to measure the relative amounts and kinds of fatty acids. We used the extraction, derivatization, and procedure detailed by Calderón et al. (2009). An internal fatty acid standard (15:0, $0.001 \mathrm{~g} \mathrm{~mL}^{-1}$ in hexane) was used to obtain quantitative data.

A separate set of sample fractions was used to measure the radioactivity in the total lipids and the lipid fractions and then in the fatty acids by thin layer chromatography (TLC). The total lipids of root sample fractions $(30 \mathrm{mg}$ ) were extracted using the method of Bligh and Dyer (1959). Briefly, $1 \mathrm{~mL}$ of $0.15 \mathrm{~mol} \mathrm{~L}^{-1}$ acetic acid and $3.75 \mathrm{~mL}$ of $2: 1 \mathrm{methanol} / \mathrm{chloroform}$ was added to each sample. The mixture was vortexed, then $1.25 \mathrm{~mL}$ of chloroform and $1 \mathrm{~mL}$ of water were added. The mixture was vortexed again, then centrifuged at low rpm to separate the phases. The bottom chloroform layer containing the total lipid was dried under $\mathrm{N}_{2}$ and resuspended in $1 \mathrm{~mL}$ of chloroform. An aliquot of known volume was placed in a glass fiber filter of known mass and dried at $75^{\circ} \mathrm{C}$ for $1 \mathrm{~h}$. The weight of the recovered lipids was measured gravimetrically and the specific activity of the lipid material in the filter was determined using the same procedure as for the plant biomass. With these data, the lipid mass and radioactivity per unit of root weight were calculated.
The fatty acid methyl esters (FAMEs) were obtained by methylating the lipid extract using the procedure of Morrison and Smith (1964). The methylation products were dried, resuspended in hexane, and used for liquid scintillation analysis and argentation TLC. The argentation TLC allowed a physical separation of the FAMEs by the number and position of double bonds as well as $\mathrm{C}$ chain length. Plate preparation, development, and visualization were performed following the methods detailed by Cahoon and Ohlrogge (1994). The FAME bands were identified by comparison with known standards (16:1, 18:1, 20:1, and 22:1, Sigma-Aldrich Chemical Co.). A commercial standard for fatty acid 16:1 $\omega 5$ was not available. For this purpose, the FAME extract from an Escherichia coli clone (pDES 16) that produces 16:1 $\omega 5,16: 1 \omega 7$, and 18: $\omega 9$ as the dominant monoenoic fatty acids was included (Schultz et al., 1996). The argentation TLC achieved a full resolution of saturated, dienoic 16:1 $\omega 5,16: 1 \omega 7$, 18:1 $\omega 7,18: 1 \omega 9$, and 20:1 FAMEs. The plates were analyzed by radiography using a Packard Instant Imager (Packard Instrument Co.) at a scan time of $1.5 \mathrm{~h}$ to measure the radiation contributed by each fatty acid band. Liquid scintillation analysis of corresponding extracts analyzed by argentation TLC plates was used to calculate the radioactivity per unit of root mass of the different FAME bands.

First-order exponential decay curves were fitted to the fatty acid radiolabel data using the Global Curve Fit feature of Sigmaplot Version 11.0 (Systat Software Inc.). In all fatty acid classes from the $\mathrm{M}$ roots, the first-order fit had a higher $R^{2}$ than a linear order fit. The mean residence time was calculated as $\mathrm{MRT}=1 / k$, where $k$ is the decomposition rate constant from the first-order decay fit.

The soil atmosphere was sampled from the plants designated for the last harvest through a port located at the bottom of the each PVC cylinder of the $4 \mathrm{M}$ and $4 \mathrm{NM}$ plants allocated to the last harvest and was measured starting at $8 \mathrm{~h}$ after the pulse label. The soil atmosphere was flushed for $10 \mathrm{~min}$ before the first sampling period, then each pot was sampled by continuously extracting air from the belowground airspace at a rate of $0.02 \mathrm{~m}^{3} \mathrm{~h}^{-1}$. The $\mathrm{CO}_{2}$ was trapped with $350 \mathrm{~mL}$ of $3 \mathrm{~mol} \mathrm{~L}^{-1}$ $\mathrm{NaOH}$, and the radioactivity was estimated using a Packard 1500 Tri-carb Liquid Scintillation Analyzer. Six sampling periods of $8 \mathrm{~h}$ were separated by 1 -h intervals between samplings. The total belowground respiration was calculated using the recovery of respired ${ }^{14} \mathrm{C}$ between 8 and $59 \mathrm{~h}$ after the pulse label. The shoot respiration was not determined separately for each plant. To calculate the shoot respiration, we assumed that the radiolabel that was not accounted for by the shoot, root, soil, and belowground respiration was the shoot respiration. Another assumption was that the shoot respiration was uniform for $\mathrm{M}$ and NM plants. Thus, we estimated a maximum value of $0.2 \mathrm{MBq}$ of shoot ${ }^{14} \mathrm{C}$ respiration.

Root-free soil samples were dried at $65^{\circ} \mathrm{C}$ and the specific activity of the soil $\mathrm{C}$ was determined in the same manner as the plant biomass. To confirm the absence of radiolabel in soil carbonates, soil samples were acidified $(0.5 \mathrm{~L}$ of 
Table 1. Biomass of inoculated (M) and uninoculated (NM) plants after the pulse label $(n=4)$. The plants were $51 \mathrm{~d}$ old at the time of the pulse exposure to ${ }^{14} \mathrm{CO}_{2}$.

\begin{tabular}{|c|c|c|c|c|c|c|c|c|c|c|}
\hline \multirow[b]{3}{*}{ Plant partt } & \multicolumn{10}{|c|}{ Plant biomass } \\
\hline & \multicolumn{2}{|c|}{ Day 52} & \multicolumn{2}{|c|}{ Day 54} & \multicolumn{2}{|c|}{ Day 57} & \multicolumn{2}{|c|}{ Day 64} & \multicolumn{2}{|c|}{ Day 76} \\
\hline & $M$ & NM & $M$ & NM & $M$ & NM & $\mathbf{M}$ & NM & $\mathbf{M}$ & NM \\
\hline & & & & & & & 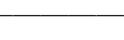 & 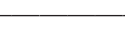 & $\overline{2}$ & \\
\hline Shoot biomass & $5.8(0.1) \ddagger$ & $6.4(0.1)$ & $6.1(0.4)$ & $6.7(0.3)$ & $7.1(0.3)$ & $7.6(0.4)$ & $9.6(0.1)$ & $9.7(0.5)$ & $14.7(0.5)$ & $16.9(1.3)$ \\
\hline Fine root biomass & $5.6(0.3)$ & $5.6(0.4)$ & $5.1(0.5)$ & $5.2(0.5)$ & $5.4(0.7)$ & $4.8(0.4)$ & $5.0(0.4)$ & $5.3(0.3)$ & $7.4(0.1)$ & $6.2(0.4)$ \\
\hline Total root biomass & $7.4(0.5)$ & $8.1(0.6)$ & $6.7(0.5)$ & $7.4(0.5)$ & $7.4(0.8)$ & $7.2(0.4)$ & $7.0(0.4)$ & $8.2(0.3)$ & $10.9(0.2)$ & $10.0(0.4)$ \\
\hline
\end{tabular}

$1 \mathrm{~mol} \mathrm{~L}^{-1} \mathrm{HCl} \mathrm{kg}^{-1}$ soil) and their specific activity was compared with unacidified samples.

All the soils from the M treatment were sampled for the concentration and radioactivity of mycorrhizal spores. The spores were obtained from 15-g soil samples by wet sieving $(38-\mu \mathrm{m}$ mesh), followed by sucrose-gradient centrifugation modified from Daniels and Skipper (1982). The spores were then transferred into a petri dish for counting under a dissecting microscope. The spores were separated from the solution by filtration (Gelman Sciences Type NE glass fiber filter), dried $\left(65^{\circ} \mathrm{C}, 24 \mathrm{~h}\right)$, then analyzed for the specific activity in the same way as the soil and plant material.

\section{Statistical Analysis}

The pots were placed in four blocks as a randomized, splitplot design, with sampling time as the main plots and mycorrhizal treatment as the subplots. The sampling times and mycorrhizal addition treatments were analyzed using the Split-Plot Analysis of Variance of SAS (SAS Institute, Cary, NC), with $n=$ 4 plants per mycorrhizae and time treatment combination.

\section{RESULTS}

\section{Plant Growth}

The plants were in an active growth phase during the 24 $\mathrm{d}$ following tracer application (Table 1). Mycorrhizal plants, the norm in most ecosystems, were comprised of $56 \%$ roots at the initiation of the labeling period. This dropped to $43 \%$ at

Table 2. Average distribution of ${ }^{14} \mathrm{C}$ per plant for the 24-d harvest period.

\begin{tabular}{|c|c|c|c|c|}
\hline \multirow{2}{*}{$\begin{array}{c}\text { Radiolabel } \\
\text { sink }\end{array}$} & \multicolumn{2}{|c|}{ Mycorrhizal plants } & \multicolumn{2}{|c|}{ Nonmycorrhizal plants } \\
\hline & Total & Allocation & Total & Allocation \\
\hline & $\mathrm{MBq}$ & $\%$ & $\mathrm{MBq}$ & $\%$ \\
\hline Shoot & $2.2(0.1)+$ & $47.9(1.3)$ & $2.1(0.1)$ & $56.5(1.2)$ \\
\hline Root & $1.3(0.1)$ & $28.9(1.9)$ & $1.0(0.1)$ & $27.3(1.9)$ \\
\hline Soil & $0.3(0.0)$ & $6.3(0.9)$ & $0.1(0.0)$ & $2.4(0.3)$ \\
\hline $\begin{array}{l}\text { Belowground } \\
\text { respiration }\end{array}$ & $0.6(\mathrm{NA} \ddagger)$ & $11.9(0.5)$ & $0.4(\mathrm{NA})$ & $10.6(1.2)$ \\
\hline Shoot respiration & $0.2(\mathrm{NA})$ & $5.0(0.2)$ & $0.2(\mathrm{NA})$ & $6.1(0.7)$ \\
\hline Total per plant & $4.6(0.2)$ & & $3.8(0.2)$ & \\
\hline
\end{tabular}

† Averages with SEM in parentheses.

₹ NA, not available. the end of the measurement period due to the relatively higher shoot growth relative to root growth. The NM plants were larger at the time of the pulse and growing at a faster pace than the $\mathrm{M}$ plants. The $\mathrm{M}$ shoot biomass increased by $153 \%$ compared with $164 \%$ in the NM plants. This difference in shoot and root growth rate is reflected in the radioactivity measurements, which show that the shoots of the NM plants contained $56 \%$ of the label relative to $47 \%$ in the M plants (Table 2). The M plants, however, had more root growth than the NM plants. Fine root biomass in the NM treatment grew by $11 \%$, while those of M plants grew by $32 \%$ (Table 1 ). The total root biomass of the $\mathrm{M}$ plants increased by $47 \%$ during the chase period compared with $23 \%$ in the NM roots.

\section{Radiolabel Assimilation}

Inoculation with mycorrhizae affected the amount of $\mathrm{C}$ assimilated and the distribution of the fixed ${ }^{14} \mathrm{C}$ to the sorghum tissues and soil. The $\mathrm{M}$ plants allocated $47.1 \%$ of their fixed ${ }^{14} \mathrm{C}$ belowground, which includes allocation to roots, soil, and belowground respiration (Table 2). The NM plants allocated $40.3 \%$. The $\mathrm{M}$ plants assimilated 21\% more labeled $\mathrm{C}$ per plant than the NM plants (Table 2). Mycorrhizae were associated with increased belowground C allocation (root, soil, and soil respiration). Belowground respiration accounted for $11.9 \%$ of the incorporated label in the $\mathrm{M}$ plants and $10.6 \%$ in the NM plants (Table 2). Infection with Glomus clarum led to an additional $0.7 \mathrm{MBq}$ of labeled C distribution to roots, soil, and soil respiration (Table 2).

The photoassimilation rate of the radiolabel by the $\mathrm{M}$ plants was $30 \%$ higher than that of the NM plants during the 3-h pulse, amounting to $0.26 \mathrm{GBq} \mathrm{kg}^{-1}$ shoot $\mathrm{h}^{-1}$ for the $\mathrm{M}$ treatment vs. $0.20 \mathrm{GBq} \mathrm{kg}^{-1}$ shoot $\mathrm{h}^{-1}$ for the NM treatment (Tables 1 and 2). The total radiolabel in the shoots and root tissues remained equal throughout the five sampling times, and this was true for both the $\mathrm{M}$ and the NM treatments (Table 3). Even though the $\mathrm{M}$ shoots had lower biomass, the total amount of radiolabel allocated to the M and NM shoot tissues was statistically indistinguishable due to higher rates of photosynthesis that produced higher specific activity in the M shoots (Table 4). 
Table 3. Total radiolabel content of the tissues and soil from mycorrhizal $(\mathrm{M})$ and nonmycorrhizal $(\mathrm{NM})$ plants $(n=4)$. The plants were $51 \mathrm{~d}$ old at the time of the pulse exposure to ${ }^{14} \mathrm{CO}_{2}$.

\begin{tabular}{llllll}
\multirow{2}{*}{$\begin{array}{c}\text { Radiolabel } \\
\text { sinkt }\end{array}$} & Day 52 & Day 54 & Day 57 & Day 64 & Day 76 \\
\cline { 2 - 6 } & \multicolumn{5}{c}{ MBq plant $^{-1}$} \\
\cline { 2 - 6 } Shoot & $2.2(0.2) \neq$ & $2.6(0.3)$ & $2.2(0.2)$ & $2.0(0.1)$ & $2.1(0.2)$ \\
M & $2.1(0.4)$ & $2.2(0.1)$ & $2.1(0.1)$ & $1.7(0.2)$ & $2.4(0.3)$ \\
NM & & & & & \\
Whole root & $1.5(0.6)$ & $1.4(0.1)$ & $1.5(0.4)$ & $1.2(0.3)$ & $1.2(0.3)$ \\
M & $1.0(0.2)$ & $1.0(0.1)$ & $1.0(0.3)$ & $1.1(0.4)$ & $1.2(0.2)$ \\
NM & & & & & \\
Fine root & $1.1(0.5)$ & $0.9(0.1)$ & $1.1(0.3)$ & $0.7(0.1)$ & $0.9(0.3)$ \\
M & $0.6(0.1)$ & $0.7(0.1)$ & $0.7(0.2)$ & $0.5(0.1)$ & $0.8(0.1)$ \\
NM & & & & & \\
Soil & $0.4(0.1)$ & $0.3(0.1)$ & $0.2(0.1)$ & $0.2(0.1)$ & $0.3(0.1)$ \\
M & $0.2(0.1)$ & $0.1(0.0)$ & $0.1(0.0)$ & $0.1(0.2)$ & $0.1(0.0)$ \\
NM & &
\end{tabular}

+ Shoot total radiolabel had no significant main effects according to ANOVA $(P<0.05)$; whole-root radiolabel had a significant mycorrhizae main effect and no significant time effect or interaction; soil total radiolabel had a significant mycorrhizae main effect and no significant time effect or interaction.

₹ Averages with SEM in parentheses.

\section{Allocation to Belowground Respiration and Soil}

The amount of ${ }^{14} \mathrm{CO}_{2}$ recovered from the belowground atmosphere decreased exponentially between 20 and $60 \mathrm{~h}$ following labeling and was consistently higher in the $\mathrm{M}$ relative to the NM treatment (Fig. 1). Each M plant evolved a total of 0.5 $\mathrm{MBq}$, while NM plants respired a total of $0.40 \mathrm{MBq}$. For both treatments, $72 \%$ of the total belowground respired ${ }^{14} \mathrm{C}$ was recovered within $34 \mathrm{~h}$ after the pulse label. The root biomass of the M plants was equal to that of the NM plants (Tables 1 and 4), which suggests higher specific rates of respiration due to fungal association with roots.

The average specific activity of the $\mathrm{M}$ soil was at least twice that of the NM soil, and this difference was measured throughout the chase period (Tables 4 and 5). This result, combined with the observed higher belowground respiration in $\mathrm{M}$ plants, demonstrates a higher allocation of fixed ${ }^{14} \mathrm{C}$ to the $\mathrm{M}$ soil relative to the NM soil. In this study, the soil specific activity at $76 \mathrm{~d}$ was lower than that measured at the first harvest (Table 4). The time effect was not significant (data not shown), however, suggesting that soil ${ }^{14} \mathrm{C}$ mineralization was negligible during the time frame of the chase period. Movement of the tracer to the soil from the roots or biota would tend to maintain its ${ }^{14} \mathrm{C}$ level.

\section{Allocation to Roots and Root Lipids}

The roots of the $\mathrm{M}$ plants had significantly higher amounts of total lipid, total fatty acids, and fatty acid 16:1w5 than NM roots (Table 5). The average concentrations of the

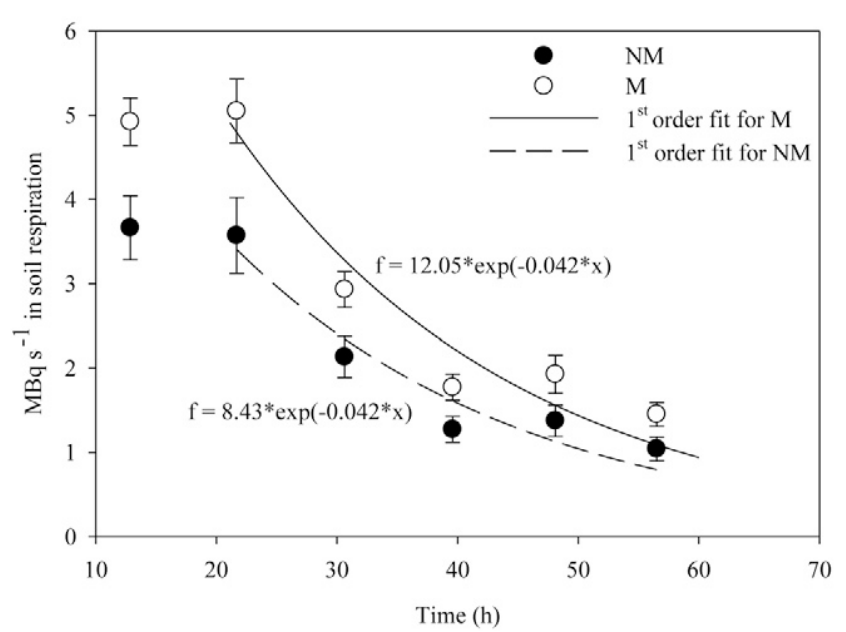

Fig. 1. Radiolabeled $\mathrm{CO}_{2}$ respiration rates from mycorrhizal $(\mathrm{M})$ and nonmycorrhizal (NM) roots.

total lipid, total fatty acids, and the biomarker $16: 1 \omega 5$ were steady throughout the 24-d chase period (Table 5). The total amount of lipids in the roots increased, however, because of the growth in root biomass (Table 1). At the time of the pulse, 16:1 1 5 made up $29.5 \%$ of the total fatty acid content of the M roots (Table 5). Previous studies from our laboratory showed that $16: 1 \omega 5$ percentages of $13.3 \%$ correspond to microscopic estimates of $44 \%$ for root colonization (data not shown), so the $\mathrm{M}$ roots had substantial fungal infection.

The radiolabel content of total lipid, total fatty acids, monoenoic fatty acids, saturated fatty acids, and 16:1 w5 was higher in $\mathrm{M}$ relative to NM fine roots (Fig. 2). In the M treatment, total extractable lipid, total fatty acid, and 16:1w5 fatty acids followed a similar pattern of high radiolabel incorporation before the first harvest, followed by a decrease in the label content throughout the chase period. In the first harvest, the total lipids and fatty acids in NM roots incorporated $30 \%$ or less of

Table 4. Specific activity of the tissues and soil from mycorrhizal (M) and nonmycorrhizal (NM) plants ( $n=4$ plants per treatment combination). The plants were $51 \mathrm{~d}$ old at the time of the pulse-exposure to ${ }^{14} \mathrm{CO}_{2}$.

\begin{tabular}{llllll}
\multirow{2}{*}{$\begin{array}{c}\text { Radiolabel } \\
\text { sinkt }\end{array}$} & Day 52 & Day 54 & \multicolumn{1}{c}{ Day 57 } & Day 64 & Day 76 \\
\cline { 2 - 4 } & & & $\mathrm{GBq} \mathrm{kg}^{-1} \mathrm{C}$ & \\
Shoot & & & & \\
M & $0.9(0.1) \neq$ & $0.9(0.1)$ & $0.7(0.1)$ & $0.5(0.0)$ & $0.3(0.0)$ \\
NM & $0.8(0.1)$ & $0.8(0.1)$ & $0.6(0.1)$ & $0.4(0.1)$ & $0.3(0.1)$ \\
Whole root & & & & \\
M & $0.5(0.2)$ & $0.5(0.1)$ & $0.5(0.1)$ & $0.4(0.2)$ & $0.2(0.1)$ \\
NM & $0.3(0.1)$ & $0.4(0.0)$ & $0.4(0.1)$ & $0.4(0.1)$ & $0.3(0.1)$ \\
Fine root & & & & & \\
M & $0.5(0.2)$ & $0.5(0.0)$ & $0.6(0.1)$ & $0.4(0.1)$ & $0.3(0.1)$ \\
NM & $0.3(0.0)$ & $0.4(0.0)$ & $0.4(0.2)$ & $0.3(0.1)$ & $0.3(0.0)$ \\
Soil & & & & & \\
M & $0.018(0.006)$ & $0.015(0.004)$ & $0.009(0.003)$ & $0.011(0.004)$ & $0.014(0.004)$ \\
NM & $0.009(0.004)$ & $0.004(0.000)$ & $0.004(0.001)$ & $0.002(0.001)$ & $0.002(0.001)$ \\
\hline
\end{tabular}

+ Shoot specific activity had significant mycorrhizae and time main effects according to ANOVA $(P<$ 0.05 ) and no interaction; whole-root specific activity had a significant mycorrhizae main effect and no significant time effect or interaction; soil specific activity had a significant mycorrhizae main effect and no significant time effect or interaction.

₹ Averages with SEM in parentheses. 
Table 5. Lipid concentrations in fine roots of mycorrhizal $(\mathrm{M})$ and nonmycorrhizal $(\mathrm{NM})$ plants $(n=4)$. Only the lipids with a concentration of $>0.25 \mathrm{~g} \mathrm{~kg}^{-1}$ for any of the sampling times are shown. The plants were $51 \mathrm{~d} \mathrm{old} \mathrm{at} \mathrm{the} \mathrm{time} \mathrm{of} \mathrm{the} \mathrm{pulse} \mathrm{exposure} \mathrm{to}{ }^{14} \mathrm{CO}_{2}$. Lipid concentration

\begin{tabular}{|c|c|c|c|c|c|c|c|c|c|c|}
\hline \multirow[b]{2}{*}{ Lipid } & \multicolumn{2}{|c|}{ Day 52} & \multicolumn{2}{|c|}{ Day 54} & \multicolumn{2}{|c|}{ Day 57} & \multicolumn{2}{|c|}{ Day 64} & \multicolumn{2}{|c|}{ Day 76} \\
\hline & $\mathbf{M}$ & NM & $\mathbf{M}$ & NM & $\mathbf{M}$ & NM & $\mathbf{M}$ & NM & $\mathbf{M}$ & NM \\
\hline Total lipidt & $26.7(3.0) \neq$ & 19.3(1.9) & ND§ & ND & $\overline{N D}^{g}$ & ND & 29.5(1.9) & $21.4(1.7)$ & 24.1(2.4) & $20.6(2.5)$ \\
\hline $\begin{array}{l}\text { Total fatty acidt } \\
\text { Mycorrhizal }\end{array}$ & $6.1(1.2)$ & $4.3(0.4)$ & $5.6(0.2)$ & $5.1(0.9)$ & $6.8(1.2)$ & $4.6(0.6)$ & $6.5(1.8)$ & $4.9(0.9)$ & $6.1(1.4)$ & $5.6(0.2)$ \\
\hline $16: 1 \omega 5+$ & $1.7(0.6)$ & $t \boldsymbol{T}$ & $1.5(0.3)$ & $\mathrm{t}$ & $1.5(0.3)$ & $0.2(0.2)$ & $1.7(0.8)$ & $\mathrm{t}$ & $1.8(0.7)$ & $t$ \\
\hline Monoenoic & & & & & & & & & & \\
\hline $17: 1$ & $\mathrm{t}$ & $0.1(0.0)$ & $0.3(0.1)$ & $\mathrm{t}$ & $0.4(0.2)$ & $0.3(0.2)$ & $0.2(0.1)$ & $0.4(0.1)$ & $0.2(0.1)$ & $0.2(0.2)$ \\
\hline $18: 1 \omega 9$ & $0.3(0.0)$ & $0.3(0.0)$ & $0.3(0.0)$ & $0.4(0.1)$ & $0.4(0.1)$ & $0.5(0.1)$ & $0.3(0.1)$ & $0.4(0.1)$ & $0.3(0.1)$ & $0.4(0.0)$ \\
\hline $18: 1 \#$ & $0.3(0.1)$ & $t$ & $0.2(0.0)$ & $t$ & $0.3(0.0)$ & $\mathrm{t}$ & $0.2(0.1)$ & $t$ & $0.2(0.1)$ & $t$ \\
\hline 19:1 & $0.6(0.1)$ & $0.9(0.1)$ & $0.4(0.1)$ & $1.1(0.2)$ & $0.6(0.1)$ & $0.8(0.1)$ & $0.5(0.1)$ & $0.7(0.3)$ & $0.4(0.1)$ & $1.1(0.1)$ \\
\hline Polyenoic & & & & & & & & & & \\
\hline $18: 2 \omega 6$ & $0.3(0.0)$ & $0.5(0.1)$ & $0.4(0.0)$ & $0.5(0.1)$ & $0.7(0.0)$ & $0.6(0.1)$ & $0.5(0.1)$ & $0.6(0.1)$ & $0.3(0.0)$ & $0.6(0.1)$ \\
\hline Saturated & & & & & & & & & & \\
\hline $16: 0$ & $1.5(0.3)$ & $0.8(0.1)$ & $1.4(0.1)$ & $0.9(0.1)$ & $1.4(0.2)$ & $0.8(0.3)$ & $1.5(0.4)$ & $1.0(0.1)$ & $1.4(0.3)$ & $0.9(0.1)$ \\
\hline $21: 0$ iso & $0.3(0.1)$ & $0.5(0.1)$ & $0.2(0.0)$ & $0.7(0.2)$ & $0.4(0.2)$ & $0.4(0.0)$ & $0.3(0.1)$ & $0.5(0.2)$ & $0.2(0.1)$ & $0.7(0.1)$ \\
\hline 21:0 & $0.7(0.1)$ & $0.7(0.1)$ & $0.5(0.1)$ & $0.9(0.2)$ & $0.7(0.1)$ & $0.7(0.1)$ & $0.7(0.2)$ & $0.8(0.2)$ & $0.7(0.2)$ & $1.1(0.1)$ \\
\hline
\end{tabular}

+ Significant mycorrhizae main effect according to ANOVA and no significant time effect or interaction $(P<0.05)$.

¥ Averages with SEM in parentheses.

$\S N D$, not determined.

It $\mathrm{t}$, trace $\left(<0.05 \mathrm{~g} \mathrm{~kg}^{-1}\right)$.

\# This is an unresolved mixture of several 18:1 isomers.

the label incorporated by the corresponding fractions in the $\mathrm{M}$ treatment (Fig. 2). The monoenoic, saturated, and 16:1 w5 fatty acids in $\mathrm{M}$ fine roots incorporated more label than $\mathrm{NM}$ and had a marked turnover of radiolabel that was not observed in the NM treatment (Fig. 2). The incorporation and turnover of radiolabel in the saturated fatty acids of $\mathrm{M}$ roots followed a similar first-order decay pattern to that of 16:1w5 (Fig. 2). The 16:1 15 MRT at $7.1 \mathrm{~d}$, however, was faster than for the rest of the fatty acids, which had an MRT average of 11 to $14 \mathrm{~d}$. In all cases, the concentration of the radiolabel approached the steady-state levels of the NM plants toward the end of the chase period.

The predominant polyenoic fatty acid in the $\mathrm{M}$ and $\mathrm{NM}$ roots was linoleic acid 18:2 (Table 5). The incorporation of ${ }^{14} \mathrm{C}$ in polyenoic fatty acids of $\mathrm{M}$ roots was small, amounting to $<5 \%$ of the total fatty acids at $1 \mathrm{~d}$ and showing little turnover in either $\mathrm{M}$ or NM roots (data not shown). The mass of 18:2 fatty acid per gram of root was lower or equal in M relative to the NM roots, suggesting that the mycorrhizal fungus was not contributing to its production. The $\mathrm{M}$ total root lipids incorporated $97.1 \mathrm{kBq}$ plant $^{-1}$ before Day 1 of the chase period, while the NM roots incorporated $28.1 \mathrm{kBq}$ (data not shown). The total fatty acids of $\mathrm{M}$ roots incorporated a total of $38.2 \mathrm{kBq}$ (Fig. 2). Thus, the total fatty acids of $\mathrm{M}$ roots accounted for $39 \%$ of the radiolabel incorporated by the total lipids between 0 and $1 \mathrm{~d}$ of the chase period. This implies that other non-fatty-acid, lipid-soluble molecules are also responsible for the relatively high radiolabel incorporation of $\mathrm{M}$ root lipids. The $\mathrm{M}$ treatment had higher lipid concentration and also higher lipid radiolabel content in the fine roots than the NM treatment. Turnover of $16: 1 \omega 5$ was significant during the chase period. In this experiment, the sporulation of the external phase of the fungus was low, with concentrations of $<1$ spore $\mathrm{g}^{-1}$ of soil recorded for all the harvest periods. Because of this, mycorrhizal spores accounted for $<0.8 \%$ of the soil radiolabel content, and we were not able to detect any turnover.

\section{DISCUSSION}

Our results have given us insight into the two hypotheses tested in this experiment. The difference between the belowground $\mathrm{C}$ allocation in $\mathrm{M}$ and $\mathrm{NM}$ sorghum roots indicates that the AMF was responsible for a translocation of nearly $4 \%$ of the photoassimilated C. This falls within the values in the literature for a variety of plant-AMF combinations. Higher values reported for ectomycorrhizal trees may be due to the significantly different nature of ectomycorrhizae and their woody plant hosts. In this study, we showed that incorporation and turnover of $16: 1 \mathrm{w5}$ is different from other fatty acids. This mycorrhizal fatty acid undergoes fast incorporation of $\mathrm{C}$ and turnover that is not observed in NM fatty acids. The dynamics of 16:1 $\omega 5$ are in agreement with the belowground respiration of $\mathrm{M}$ plants and can be used as an indicator of $\mathrm{C}$ demand and utilization by the fungus.

\section{Plant Growth}

The lower shoot biomass of the $\mathrm{M}$ plants indicates that there was incomplete compensation of the $\mathrm{C}$ demand of the fungus in the $\mathrm{M}$ symbiosis. Previous experiments have shown that plants may meet the $\mathrm{C}$ needs of the mycorrhizal symbiont by assimilating more C (Paul and Kucey, 1981; Kucey and Paul, 1982). It has been hypothesized that the positive effect of mycorrhizal fungi on the photosynthetic rate is explained by improvement in the water balance, increased leaf tissue $\mathrm{P}$, higher specific leaf area, or phytohormones associated with mycorrhizal infection (Harris et al., 1985). We observed no statistical difference in tissue $\mathrm{P}$ between $\mathrm{M}$ and $\mathrm{NM}$, so 


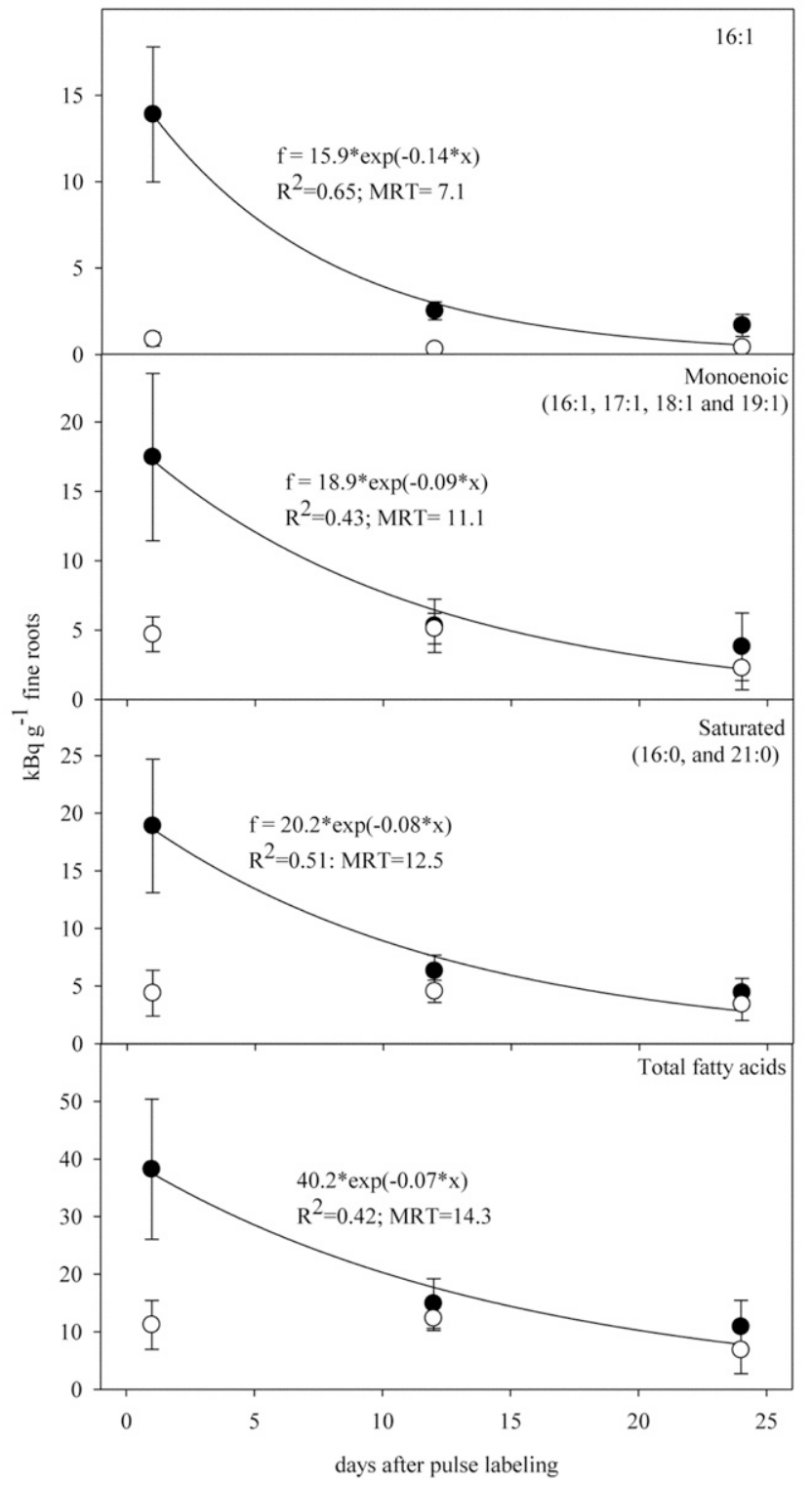

Fig. 2. Radiolabel decay in different root lipid classes from mycorrhizal (M, black circles) and nonmycorrhizal (NM, white circles) roots determined by thin-layer chromatography and radiography.

the increased photosynthetic rate in $\mathrm{M}$ shoots cannot be explained by $\mathrm{P}$ nutrition. There was no mycorrhizal effect on the root biomass, even though $\mathrm{M}$ roots grew more rapidly during the chase period. Other studies have shown instances where mycorrhizal plants did not significantly increase root biomass but instead increased leaf area and photosynthetic rate (Miller et al., 2002). The sink strength of mycorrhizal roots creates an additional demand that drains $C$ from the plant and can limit vegetative growth, and this pattern increases with P deficiency (Miller et al., 2002).

\section{Radiolabel Assimilation}

Other pulse-chase experiments have shown that $\mathrm{M}$ plants fix more $\mathrm{C}$ and allocate more fixed $\mathrm{C}$ to $\mathrm{M}$ roots compared with NM plants, despite differences in growth media, pulse and chase periods, host-fungus combinations, and plant ages (Pang and Paul, 1980; Snellgrove et al., 1982; Jakobsen and Rosendahl, 1990; Tinker et al., 1994). Vandenkoornhuyse et al. (2007) showed that there is significantly higher $\mathrm{C}$ flux from the plant to the AMF compared with other root-inhabiting microbes. The increase in $\mathrm{C}$ allocation to mycorrhizae may be accounted for by several factors: (i) fungal respiration, (ii) root respiration, (iii) allocation to mycelial biomass, (iv) allocation to root biomass, (v) mycelial respiration (external), and (vi) exudation from roots or hyphae. Mycorrhizal-rhizobial plants have been found to have a higher fixation rate than uninoculated plants; however, the growth rate of the symbiotic plants was less than that that of the uninoculated plants because of the allocation of photosynthate to the symbionts (Harris et al., 1985). Snellgrove et al. (1982) found a similar pattern in Allium infected with Glomus. Other studies have found that $\mathrm{M}$ plants had similar or higher growth rates relative to NM plants, implying that the host compensated for the $\mathrm{C}$ demand from the symbionts with an increased photosynthetic rate (Pang and Paul, 1980; Paul and Kucey, 1981). Higher soil fertility may result in a parasitic-like relationship, whereas the AMF may act as a mutualist when it can help obtain limiting resources such as soil $\mathrm{P}$.

Shoots of M plants received $48 \%$ of the ${ }^{14} \mathrm{C}$, while the roots received 29\% and the soil 6.3\% (not taking in account respired ${ }^{14} \mathrm{C}$ ). Warembourg and Paul (1973) found that $65 \%$ of the ${ }^{14} \mathrm{C}$ was retained aboveground and $35 \%$ belowground in a mixed prairie system. The lack of decay in the shoot radiolabel suggests that the majority of the $\mathrm{C}$ remaining in the plants $24 \mathrm{~h}$ after the ${ }^{14} \mathrm{C}$ pulse was incorporated into long-term storage or structural components. Root specific activity remained unchanged throughout the chase period. Warembourg and Paul (1977) found that the half-life of prairie roots in the field was $107 \mathrm{~d}$, suggesting that the time frame of our experiment may have been too short to detect decay and turnover of whole roots. In our study, $\mathrm{M}$ roots had significantly higher specific activity and total radiolabel content than the NM roots (Tables 3 and 4). The roots in our study were actively growing during the chase period and radiolabel was incorporated into structural and storage root components.

\section{Allocation to Belowground Respiration and Soil}

Our results agree with previous studies that have shown increased root respiration of M plants relative to NM plants using pulse-chase experiments with different plant-fungus combinations (Pang and Paul, 1980; Kucey and Paul, 1982; Snellgrove et al., 1982; Harris et al., 1985; Johnson et al., 2002). The radiolabel in the $\mathrm{M}$ and NM belowground respiration remained stable for the initial $21 \mathrm{~h}$, suggesting that this was a period of photosynthate translocation from shoots to roots (Kuzyakov and Gavrichkova, 2010). The $\mathrm{CO}_{2}$ evolution after $60 \mathrm{~h}$ approached the point where movement of label from the foliage to the roots had finished and the label had been translocated to root and mycorrhizal structural and storage and soil $\mathrm{C}$ pools such as chitin and glomalin (Zhu and Miller, 2003).

There is great interest in C cycling studies in the separation of autotrophic from heterotrophic respiration (Hahn et al., 2006). It is hard to determine whether mycorrhizal fungal respiration is part of the autotrophic or heterotrophic cycle. The 
AMF receives its $\mathrm{C}$ directly from the plant host and does not rely on the decomposition of plant residues. The fast cycling of the fungal fatty acids associated with the AMF in our study, together with significant movement of the tracer to the soil, leads us to suggest that although fungal in origin, this respiration is most closely associated with the autotrophic processes and should be considered as such.

Microbial decomposition of root exudates can be an important source of belowground $\mathrm{CO}_{2}$ production (Martin and Kemp, 1986). Decreased root exudation and rhizosphere respiration has been shown in mycorrhizal plants (Graham et al., 1981; Miller et al., 2002). If the latter case is true, the increase in belowground ${ }^{14} \mathrm{CO}_{2}$ from the $\mathrm{M}$ soil could be accounted for by an increased specific respiration rate of the roots or the respiration of the AMF hyphae. Previous studies have shown contrasting evidence regarding increases in soil $\mathrm{C}$ allocation associated with AMF. Snellgrove et al. (1982) found a marginal difference, while Jakobsen and Rosendahl (1990) found that the allocation of $\mathrm{C}$ to the extraradical phase was twice that of NM plants and represented $3.1 \%$ of the total $\mathrm{C}$ fixation by the plant. Johnson et al. (2002) found that the amount of ${ }^{14} \mathrm{C}$ allocated into mycorrhizal mycelium 0 to $70 \mathrm{~h}$ after labeling accounted for $3.4 \%$ of the ${ }^{14} \mathrm{C}$ initially fixed by the plants. Paul and Kucey (1981) observed that extraradical mycorrhizal hyphae accounted for $1 \%$ of the fixed $\mathrm{C}$ in a $\mathrm{C}_{3}$ plant. The difference between the $6.3 \% \mathrm{C}$ allocation to the soil in the $\mathrm{C}_{4}$ sorghum plants relative to $2.4 \%$ in the NM plants in our study could be attributed to mycorrhizal hyphae and their metabolites in the soil. If we assume that the label incorporation rates between the AMF and the plant root cells were similar and that most of the radiolabel incorporation into the soil ended up as fungal biomass, then we can estimate the extraradical AMF biomass/root ratio as $6.3 / 28.9$ or $22 \%$. It is important to keep in mind that this may be an overestimate because others have shown that plant-assimilated $\mathrm{C}$ is quickly translocated to AMF (Olsson and Johnson, 2005), followed by a slow transfer to soil microbial populations starting 4 to $5 \mathrm{~d}$ after labeling. Root exudation has been said to reach levels of 5 to $21 \%$ of the photosynthate (Walker et al., 2003). Hinsinger et al. (2012) have estimated C loss by deposition to approximate $11 \%$. Our data and the results quoted for fairly mature plants in natural soils indicate much lower levels. Many of the high results have come from very young plants and NM plants grown in sand or nutrient cultures.

It is important to note that in this study the mineralization of extramatrical hyphae might have been affected by the possible lack of soil fauna in the experimental soils. This has been conjectured before in similar experiments where soils were sterilized before inoculation with AMF (Olsson and Johnson, 2005). Reduced soil fauna could have resulted in diminished grazing of fungal structures in the soil and the observed low soil ${ }^{14} \mathrm{C}$ mineralization.

A large number of $\mathrm{C}$ allocation experiments in mycorrhizal systems have been performed using $\mathrm{C}_{3}$ plants. Sorghum is a $\mathrm{C}_{4}$ plant, and studies are showing that root exudation differs between $\mathrm{C}_{3}$ and $\mathrm{C}_{4}$ plants (Phillips et al., 2006). More studies are needed about possible differences between $\mathrm{C}_{3}$ and $\mathrm{C}_{4}$ plants regarding allocation of photosynthate to soil hyphae vs. root exudates because this may have an important influence in the priming of soil $\mathrm{C}$ mineralization and sequestration.

\section{Allocation to Roots and Root Lipids}

The increased accumulation of lipids in mycorrhizae has been documented by previous studies (Cooper and Losel, 1978; Nagy et al., 1980; Peng et al., 1993). A significant fraction of the lipids of several Glomus species may be comprised of the unusual fatty acid 16:1 15 (Calderón et al., 2009), and this molecule has been proposed as the principal AMF storage molecule in intraradical vesicles (Pacovsky and Fuller, 1988). Because of the increased production of lipids, infection with AMF has an associated increase in the cost of root production.

It has been conjectured that the $\mathrm{C}$ sink strength of mycorrhizae involves the unidirectional transfer of photosynthate into fungal-specific compounds (Losel and Cooper, 1979). The concentration of $16: 1 \omega 5$ fatty acid in roots increases with the formation of fungal storage structures (Graham and Hodge, 1993). Our results indicate that lipids are a dynamic $\mathrm{C}$ pool that could play a role in unidirectional C transfer. Wiesenberg et al. (2010) showed that in perennial ryegrass (Lolium perenne L.), lipid C moves from roots into the soil and that roots, rather than litterfall, are the main source of soil lipids. Pfeffer et al. (1999) showed that the AMF converts sugars inside the roots into lipids that then move to the extraradical mycelium, with no lipid synthesis in the external mycelium.

The turnover of radiolabel in NM lipids was slight or absent during the chase period. In contrast, the $M$ fatty acids of all types showed a measurable decay in radiolabel. We hypothesize that a portion of the saturated fatty acids such as 16:0 in M roots also represents a dynamic fungal pool. The faster MRT of the 16:1 $\omega_{5}$ may be partly due to the fast turnover of membrane-rich AMF structures such as arbuscules, which are created and senesce faster than other fungal structures (Cox and Tinker, 1976). The MRT of fatty acid 16:1 $\omega 5$ at $7 \mathrm{~d}$ was within the turnover time frame of the fungal arbuscules reported by Cox and Tinker (1976), who calculated that fungal arbuscules have a life span of 4 to 15 $\mathrm{d}$ within the root cells, after which time they are reabsorbed by the plant cell. Balasooriya et al. (2008) found the mycorrhizalspecific fatty acids to have a MRT of $4 \mathrm{~d}$ in a grassland under field conditions. These results verify the relatively fast turnover of mycorrhizal structures. Such short turnover is probably a prerequisite to an efficient symbiotic system.

The 18:2 fatty acid, with its low amount of radiolabel incorporation and turnover, could be considered a component of plant biomass rather than of AMF biomass. This may explain the similar C cycle of 18:2 fatty acid of M and NM roots. The fact that non-fatty-acid root lipids made up a large portion of lipid label incorporation and turnover in $\mathrm{M}$ roots shows that other lipid forms such as alkanes and sterols are also important in the $\mathrm{C}$ cycling of $\mathrm{M}$ roots. The concentration non-fatty-acid lipids such as sterols, 
waxes, and carotenoids may be affected by mycorrhizal infection (Nagy et al., 1980; Nordby et al., 1981; Schmitz et al., 1991).

Recycling of tracer may occur between lipid and non-lipid pools. In fungi, carbohydrates may be converted to fat and vice versa via the glyoxylate pathway (Weete, 1980). There is also a likelihood that some recycling occurs between the fungus and the host plant. Fatty acid 16:1 $\omega 5$ may exist free in the cytoplasm or be bound to different lipid classes such as triglycerides, diglycerides, or phospholipids. Triglycerides are thought to serve as long-term storage of $\mathrm{C}$, while phospholipids serve a structural function by being part of cellular membranes. We hypothesize that 16:1 w5 obtained from whole-cell extracts may consist of a mixture of different $\mathrm{C}$ pools, with the possibility that each pool has a $\mathrm{C}$ cycle of a different time span. The low sporulation found in this study indicates that the increased ${ }^{14} \mathrm{C}$ content of the $\mathrm{M}$ soil relative to the NM soil cannot be explained by fungal sporulation. Other factors such as fungal hyphae and $\mathrm{C}$ immobilization in soil saprophytes may explain the response in radiolabel content of the $\mathrm{M}$ soil.

\section{CONCLUSIONS}

Belowground transfers of photosynthate are especially important to the functioning of roots and their associated microbial communities. Their size needs to be known in interpreting ecosystem functioning and soil $\mathrm{CO}_{2}$ fluxes. Previous studies have shown that photosynthate is quickly translocated to root and soil fatty acids, and 16:1 $\omega 5$ receives a large portion of the $C$ (De Deyn et al., 2011). Our study, with the benefit of a NM control, confirms that $16: 1 \omega 5$ is a mycorrhizal pool. The $M$ treatment should be viewed as the normal state of plant physiology because the NM treatment would rarely be observed in nature. We have shown that the higher root respiration and large movement of ${ }^{14} \mathrm{C}$ underground is a consequence of mycorrhizae. The allocation of $6.3 \%$ of the photosynthate to the soil is higher than other results obtained in our laboratory that tended to show values of 1 to $3 \%$. The value of $6.3 \%$ of soil allocation represents $18 \%$ of the belowground production.

The separation of the mycorrhizal fatty acids is useful from both quantitative and qualitative standpoints because it allows, for the first time, calculation of the turnover of an important cytoplasmic component of the AMF. Our results suggest that the net effect of the AMF is to increase the $\mathrm{C}$ storage in root lipids, despite the high losses of $\mathrm{C}$ associated with the metabolism of the mycorrhizal fungus. Fatty acid $16: 1 \omega 5$ is not a long-term structural molecule and does not necessarily give a total turnover of the AMF biomass. Fatty acids account for a high percentage of the AMF cytoplasm, however, so the turnover rate of the mycorrhizal fatty acids represents the $\mathrm{C}$ turnover of an important C pool of the fungus. In this experiment, we measured the incorporation followed by a sustained decrease in the content of ${ }^{14} \mathrm{C}$ of the $16: 1 \omega 5$ fatty acid during the $24-\mathrm{d}$ chase period. This pattern is absent in the nonmycorrhizal roots and represents an important difference in the $\mathrm{C}$ physiology and $\mathrm{C}$ economy of the mycorrhizal fungus and the host. This technique opens the pos- sibility of further experiments to study environmental impacts on the turnover of mycorrhizal components.

\section{REFERENCES}

Bago, B., C. Azcon-Aguilar, A. Goulet, and Y. Piché. 1998. Branched absorbing structures (BAS): A feature of the extraradical mycelium of symbiotic arbuscular mycorrhizal fungi. New Phytol. 139:375-388. doi:10.1046/ j.1469-8137.1998.00199.x

Balasooriya, W.K., K. Denef, J. Peters, N.E.C. Verhoest, and P. Boeckx. 2008. Vegetation composition and soil microbial community structural changes along a wetland hydrological gradient. Hydrol. Earth Syst. Sci. 12:277291. doi: 10.5194/hess-12-277-2008

Balestrini, R., V. Bianciotto, P. Bonfante, M. Schloter, S. Srinivasiah, R.G. Thorn, et al. 2011. Microbiota. In: P.M. Huang et al., editors, Handbook of soil sciences: Properties and processes. 2nd ed. CRC Press, Boca Raton, FL. p. 24-1-24-35.

Beilby, J.P. 1980. Fatty acid and sterol composition of ungerminated spores of the vesicular-arbuscular mycorrhizal fungus Acaulospora laevis. Lipids 15:949952. doi:10.1007/BF02534420

Bligh, E.G., and W.M. Dyer. 1959. A rapid method of lipid extraction and purification. Can. J. Biochem. Physiol. 35:911-917. doi:10.1139/059-099

Cahoon, E.B., and J.B. Ohlrogge. 1994. Apparent role of phosphatidylcholine in the metabolism of petroselinic acid in developing Umbelliferae endosperm. Plant Physiol. 104:845-855.

Calderón, F.J., V. Acosta-Martinez, D.D. Douds, Jr., J.B. Reeves III, and M.F. Vigil. 2009. Mid-infrared and near-infrared spectral properties of mycorrhizal and non-mycorrhizal root cultures. Appl. Spectrosc. 63:494-500.

Cooper, K., and D. Losel. 1978. Composition of lipids in roots of onion, clover, and ryegrass infected with Glomus mosseae. New Phytol. 80:143-151. doi:10.1111/j.1469-8137.1978.tb02274.x

Cox, G., F.E. Sanders, P.B. Tinker, and J.A. Wild. 1975. Ultrastructural evidence relating to host-endophyte transfer in vesicular-arbuscular mycorrhizae. In: F.E. Sanders et al., editors, Endomycorrhizas. Academic Press, London. p. $149-174$.

Cox, G., and P.B. Tinker. 1976. Translocation and transfer of nutrients in vesicular- arbuscular mycorrhizae: 1 . The arbuscle and phosphorus transfer: A quantitative ultrastructural study. New Phytol. 77:371-378. doi:10.1111/j.1469-8137.1976.tb01526.x

Daniels, B.A., and H.D. Skipper. 1982. Methods for the recovery and quantitative estimation of propagules from soil. In: N.C. Schenck, editor, Methods and principles of mycorrhizal research. Am. Phytopathol. Soc. Press, St. Paul, MN. p. 29-35.

De Deyn, G.B., H. Quirk, S. Oakley, N. Ostle, and R.D. Bardgett. 2011. Rapid transfer of photosynthetic carbon through the plant-soil system in differently managed species-rich grasslands. Biogeosciences 8:1131-1139. doi:10.5194/bg-8-1131-2011

Denef, K., D.R. Dries, C. Mihiri, M. Wadu, P. Lootens, and B. Pascal. 2009. Microbial community composition and rhizodeposit-carbon assimilation in differently managed grassland soils. Soil Biol. Biochem. 41:144-153. doi:10.1016/j.soilbio.2008.10.008

Finlay, R., and B. Soderstrom. 1992. Mycorrhizae and carbon flow to soil. In: M. Allen, editor, Mycorrhizal functioning. Chapman \& Hall, New York. p. $134-170$.

Graham, J.H., and N.C. Hodge. 1993. Evaluation of carbon cost of citrus mycorrhizae by fatty acid analysis. In: L. Peterson and M. Schelkle, editors, Abstracts of the 9th North American Conference on Mycorrhizae, Guelph, ON, Canada. 8-12 Aug. 1993. Univ. of Guelph, Guelph, ON, Canada.

Graham, J.H., R.T. Leonard, and J.A. Menge. 1981. Membrane-mediated decrease in root exudation responsible for phosphorus inhibition of vesicular-arbuscular mycorrhiza formation. Plant Physiol. 68:548-552. doi:10.1104/pp.68.3.548

Grandmougin-Ferjani, A., Y. Dalpe, M.A. Hartmann, F. Laruelle, D. Couturier, and M. Sancholle. 1997. Taxonomic aspects of the sterol and delta 11-hexadecenoic acid (C16:1 delta 11) distribution in arbuscular mycorrhizal spores. In: J.P. Williams et al., editors, Physiology, biochemistry and molecular biology of plant lipids. Kluwer Acad. Publ., Dordrecht, the Netherlands. p. 198. 
Hahn, V., P. Hogberg, and N. Buchmann. 2006. ${ }^{14} \mathrm{C}$ : A tool for separation of autotrophic and heterotrophic soil respiration. Global Change Biol. 12:972982. doi:10.1111/j.1365-2486.2006.001143.x

Harris, D., R. Pacovsky, and E.A. Paul. 1985. Carbon economy of soybean-Rhizobium-Glomus associations. New Phytol. 101:427-440. doi:10.1111/j.1469-8137.1985.tb02849.x

Hinsinger, P., D.L. Jones, and P. Marschner. 2012. Biogeochemical, biophysical and biological processes in the rhizosphere. In: P.M. Huang et al., editors, Handbook of soil sciences: Resource management and environmental impacts. 2nd ed. CRC Press, Boca Raton, FL. p. 6-1-6-30.

Hobbie, E. 2006. Carbon allocation to ectomycorrhizal fungi correlates well with belowground allocation in culture studies. Ecology 87:563-569. doi: 10.1890/05-0755

Jakobsen, I., and L. Rosendahl. 1990. Carbon flow into soil and external hyphae from roots of mycorrhizal cucumber plants. New Phytol. 115:77-83. doi:10.1111/j.1469-8137.1990.tb00924.x

Johnson, D., J.R. Leake, and D.J. Read. 2002. Transfer of recent photosynthate into mycorrhizal mycelium of an upland grassland: Short-term respiratory losses and accumulation of ${ }^{14} \mathrm{C}$. Soil Biol. Biochem. 34:1521-1524. doi: 10.1016/S0038-0717(02)00126-8

Kramer, C., and G. Gleixner. 2006. Variable use of plant- and soil-derived carbon by microorganisms in agricultural soils. Soil Biol. Biochem. 38:32673278. doi:10.1016/j.soilbio.2006.04.006

Kucey, R., and E.A. Paul. 1982. Carbon flow, photosynthesis, and $\mathrm{N}_{2}$ fixation in mycorrhizal and nodulated faba beans (Vicia faba L.). Soil Biol. Biochem. 14:407-412. doi:10.1016/0038-0717(82)90013-X

Kuzyakov, Y., and O. Gavrichkova. 2010. Time lag between photosynthesis and carbon dioxide efflux from soil: A review of mechanisms and controls. Global Change Biol. 16:3386-3406. doi:10.1111/j.13652486.2010.02179.x

Leake, J.R., N.J. Ostle, J. Rangel-Castro, and J. Johnston. 2006. Carbon fluxes from plants to soil microorganisms determined by field ${ }^{13} \mathrm{CO}_{2}$ pulse labelling to an upland grassland soils. Appl. Soil Ecol. 33:152-175. doi:10.1016/j.apsoil.2006.03.001

Losel, D.M., and K.M. Cooper. 1979. Incorporation of ${ }^{14} \mathrm{C}$-labelled substrates by uninfected and VA mycorrhizal roots of onion. New Phytol. 83:415431. doi:10.1111/j.1469-8137.1979.tb07466.x

Martin, J., and J. Kemp. 1986. The measurement of C transfers within the rhizosphere of wheat grown in field plots. Soil Biol. Biochem. 18:103-107. doi:10.1016/0038-0717(86)90110-0

Miller, R.M., S.P. Miller, J.D. Jastrow, and C.B. Rivetta. 2002. Mycorrhizal mediated feedbacks influence net carbon gain and nutrient uptake in Andropogon gerardii. New Phytol. 155:149-162. doi:10.1046/j.14698137.2002.00429.x

Morrison, W.R., and L.M. Smith. 1964. Preparation of fatty acid methyl esters and dimethyl acetals from lipids with boron fluoride-methanol. J. Lipid Res. 5:600-607.

Nagy, S., H.E. Nordby, and S. Nemec. 1980. Composition of lipids in roots of six citrus cultivars infected with the vesicular-arbuscular mycorrhizal fungus Glomusmosseae. New Phytol.85:377-384.doi:10.1111/j.1469-8137.1980. tb03176.x

Nordby, H.E., S. Nemec, and S. Nagy. 1981. Fatty acids and sterols associated with citrus root mycorrhizae. J. Agric. Food Chem. 29:396-401. doi:10.1021/jf00104a043

Olsson, P.A., and N.C. Johnson. 2005. Tracking carbon from the atmosphere to the rhizosphere. Ecol. Lett. 8:1264-1270. doi:10.1111/j.14610248.2005.00831.x

Pacovsky, R.S., and G. Fuller. 1988. Mineral and lipid composition of Glycine-Glomus-Bradyrhizobium symbioses. Physiol. Plant. 72:733-746. doi:10.1111/j.1399-3054.1988.tb06373.x
Pang, P., and E.A. Paul. 1980. Effects of vesicular-arbuscular mycorrhiza on ${ }^{14} \mathrm{C}$ and ${ }^{15} \mathrm{~N}$ distribution in nodulated faba beans. Can. J. Soil Sci. 60:241250. doi: $10.4141 /$ cjss80-027

Paul, E.A., and R. Kucey. 1981. Carbon flow in plant-microbial associations. Science 213:473-474. doi:10.1126/science.213.4506.473

Peng, S., D.M. Eissenstat, J.H. Graham, K. Williams, and N.C. Hodge. 1993. Growth depression in mycorrhizal citrus at high-phosphorus supply: Analysis of carbon costs. Plant Physiol. 101:1063-1071.

Pfeffer, P.E., D.D. Douds, G. Bécard, and Y. Shachar-Hill. 1999. Carbon uptake and the metabolism and transport of lipids in an arbuscular mycorrhiza. Plant Physiol. 120:587-598. doi:10.1104/pp.120.2.587

Phillips, D., T. Fox, and J. Six. 2006. Root exudation (net efflux of amino acids) may increase rhizodeposition under elevated $\mathrm{CO}_{2}$. Global Change Biol. 12:561-567. doi:10.1111/j.1365-2486.2006.01100.x

Rillig, M., and M. Allen. 1999. What is the role of arbuscular mycorrhizal fungi in plant ecosystem responses to elevated atmospheric $\mathrm{CO}_{2}$ ? Mycorrhiza 9:1-8. doi:10.1007/s005720050257

Schmitz, O., B. Danneberg, A. Hundeshagen, A. Klingner, and H. Bothe. 1991. Quantification of vesicular-arbuscular mycorrhiza by biochemical parameters. J. Plant Physiol. 139:106-114. doi:10.1016/S0176-1617(11)80174-4

Schultz, D.J., E.B. Cahoon, J. Shanklin, R. Craig, D.L. Cox-Foster, R.O. Mumma, and J.I. Medford. 1996. Expression of a delta 14:0-acyl carrier protein fatty acid desaturase gene is necessary for the production of omega 5 anacardic acids found in pest-resistant geranium (Pelargonium $\times$ hortum). Proc. Natl. Acad. Sci. 93:8771-8775. doi:10.1073/pnas.93.16.8771

Snellgrove, R., W. Splittstoesser, D. Stribley, and P. Tinker. 1982. The distribution of carbon and the demand of the fungal symbiont in leek plants infected with vesicular- arbuscular mycorrhizas. New Phytol. 92:75-87. doi:10.1111/j.1469-8137.1982.tb03364.x

Staddon, P.L., A.H. Fitter, and D. Robinson. 1999. Effects of mycorrhizal colonization and elevated atmospheric carbon dioxide on carbon fixation and below-ground carbon partitioning in Plantago lanceolata. J. Exp. Bot. 50:853-860. doi:10.1093/jxb/50.335.853

Tinker, P., D.M. Durall, and M.D. Jones. 1994. Carbon use efficiency in mycorrhizas: Theory and sample calculations. New Phytol. 128:115-122. doi:10.1111/j.1469-8137.1994.tb03994.x

Vandenkoornhuyse, P., S. Mahe, P. Ineson, P. Staddon, N. Ostle, J.B. Cliquet, et al. 2007. Active root-inhabiting microbes identified by rapid incorporation of plant derived carbon into RNA. Proc. Natl. Acad. Sci. 104:1697016975. doi:10.1073/pnas.0705902104

Walker, T.S., H.P. Bais, E. Grotewold, and J.M. Vivanco. 2003. Root exudation and rhizosphere biology. Plant Physiol. 132:44-51. doi:10.1104/ pp.102.019661

Warembourg, F.R., and E.A. Paul. 1973. The use of $\mathrm{C}^{14} \mathrm{O}_{2}$ canopy techniques for measuring carbon transfer through the plant-soil system. Plant Soil 38:331-345. doi:10.1007/BF00779017

Warembourg, F.R., and E.A. Paul. 1977. Seasonal transfers of assimilated ${ }^{14} \mathrm{C}$ in grassland: Plant production and turnover, soil and plant respiration. Soil Biol. Biochem. 9:295-301. doi:10.1016/0038-0717(77)90038-4

Weete, J.D. 1980. Fungal lipids. In: J.D. Weete, editor, Lipid biochemistry of fungi and other organisms. Plenum Press, New York. p. 388.

Wiesenberg, G.L.B., M. Gocke, and Y. Kuzyakov. 2010. Fast incorporation of root-derived lipids and fatty acids into soil: Evidence from a short term multiple ${ }^{14} \mathrm{CO}_{2}$ pulse labelling experiment. Org. Geochem. 41:10491055. doi:10.1016/j.orggeochem.2009.12.007

Zhu, Y.G., and R.M. Miller. 2003. Carbon cycling by arbuscular mycorrhizal fungi in soil-plant systems. Trends Plant Sci. 8:407-409. doi:10.1016/ S1360-1385(03)00184-5 